\title{
Melanom, føflekk eller talgvorte?
}

\author{
Det kan være vanskelig å skille mellom malignt melanom, pigmentnævus og seboreisk keratose. Bruk av \\ kyrette og stanseeksisjon er enkle prosedyrer som kan utføres i allmennpraksis for å avklare diagnosen.
}

\begin{abstract}
Diagnostikk av malignt melanom kan være vanskelig. Spesielt kan seboreiske keratoser (talgvorter eller gammelmannsvorter) og pigmentnævi (føflekker) forveksles med malignt melanom.

Vi presenterer her, med tekst og video, tre enkle prosedyrer som allmennlegen kan utføre for å gi pasientene raskere diagnose, og - ved malignt melanom - tidligere behandling og bedre prognose.
\end{abstract}

\section{Seboreiske keratoser}

Seboreiske keratoser er epidermale hyperkeratoser uten malignitetspotensial. Slike lesjoner er svært vanlig hos eldre og er den mest aktuelle differensialdiagnosen ved mistanke om malignt melanom hos personer over 40 år. Seboreiske keratoser oppstår over uker til måneder i voksen alder. Lesjonene kan variere i farge, fra lysebrune til brunsvarte (fig 1) og kan løsne ved berøring eller små traumer. De etterlater seg da små, forbigående erosjoner, men kan komme tilbake på samme sted. Ved dermatoskopi vil en seboreisk keratose ha et karakteristisk utseende med verrukøs overflate og talgdråper (1). Slike lesjoner vil vanligvis være enkle å diagnostisere med sikkerhet.

Er det likevel tvil om diagnosen, bør lesjonen fjernes med en kyrette (video 1). Prosedyren er rask, lett å utføre og krever ingen oppdekking eller suturering. Dersom et keratotisk materiale lar seg fjerne enkelt og etterlater en jevn, hvitlig, lettblødende overflate (video 1), er diagnosen seboreisk keratose bekreftet. Det kyretterte materialet bør ved fortsatt tvil sendes til histologisk undersøkelse.

\section{Atypiske pigmentnævi}

Pigmentnævi med diameter $>5 \mathrm{~mm}$, uregelmessig form og varierende farge betegnes i dermatologisk litteratur som atypiske eller dysplastiske pigmentnævi. De har alltid en makuløs (dvs. flat) komponent (2).

Personer med fem eller flere atypiske pigmentnævi har 5-10 ganger høyere risiko for å utvikle kutant malignt melanom enn personer uten atypiske pigmentnævi (3). Slike lesjoner er en indikator for en hudtype som lettere utvikler malignt melanom, snarere enn et mulig forstadium til melanom i seg selv (2).

Dermatoskopi kan være til hjelp i diagnostikken, men krever både opplæring og erfaring, noe de fleste allmennleger ikke har (4). Fordi det kan være vanskelig å skille en atypisk pigmentnævus fra et malignt melanom, vil man ved tvil måtte foreta en eksisjon for sikker diagnostisk avklaring. Fjerning av mindre pigmentnævi, inkludert atypiske pigmentnævi, kan utføres ved hjelp av en kniv med sirkulært blad (video 2). Lesjonen bør fjernes med fri rand. Histologisk undersøkelse vil avklare diagnosen. Hvis lesjonen er større enn $6 \mathrm{~mm}$ bør en ordinær, båtformet eksisjon foretrekkes (video 3).

\section{Malignt melanom}

Malignt melanom er en alvorlig form for kreft som utgår fra melanocytter, vanligvis i hud.

Tidlig diagnostikk og behandling med eksisjon bedrer overlevelsen. De vanligste og viktigste faresignalene er vekst og fargeforandring, særlig utvikling av sorte partier. Pigmenterte lesjoner som avviker fra andre ved sitt utseende eller sin utvikling, ofte omtalt som den stygge andungen-tegnet, bør vies særlig oppmerksomhet. ABCDEregelen (ramme 1) er noe mer komplisert og er mest aktuell for helsepersonell $(6,7)$. Regelen baserer seg på at de fleste maligne melanomer er asymmetriske, har en uregelmessig avgrensning, har fargevariasjon med svarte partier, har diameter over $6 \mathrm{~mm}$ og at de har endret seg. ABCDE-regelen er egnet for å identifisere mange tilfeller av melanom, men i mindre grad noduløse varianter; disse har symmetrisk form og samtidig dårligst prognose (8).

Dersom legen mistenker eller ikke kan utelukke diagnosen malignt melanom, bør lesjonen eksideres i sin helhet med minst $2 \mathrm{~mm}$ fri rand, enten med en stanse (video 2) eller en båtformet eksisjon (video 3 ). Dette er prosedyrer som alle allmennleger bør beherske. Dersom de ikke gjør det, skal pasienten henvises med klar og entydig formulert henvisning til hudlege eller kirurg, som bør ta imot pasientene senest innen to uker (9).

\section{Seboreiske keratoser versus malignt melanom}

Seboreiske keratoser kan klø, vokse raskt og ha en mørk farge med svarte partier. De kan derfor være vanskelig å skille fra malignt melanom på klinisk grunnlag alene. At pasienten har flere lesjoner med samme eller tilnærmet samme utseende, taler sterkt for diagnosen seboreiske keratoser. Deres stearinaktige eller verrukøse konsistens ved palpasjon skiller dem fra atypiske pigmentnævi og malignt melanom.

Overflatisk spredende malignt melanom er den vanligste formen for melanom. Slike lesjoner kan være makuløse eller bare lett eleverte. Overflaten er som regel jevn, ikke fetlig og sjelden verrukøs. Et nodulært malignt melanom har oftest en jevn avgrensning, men kan vokse fort og samtidig være under $6 \mathrm{~mm}$ i diameter. Overflaten er sjelden verrukøs.

\section{Atypisk pigmentnævus versus malignt melanom}

Atypiske pigmentnævi vil vanligvis ikke klø, men kløe er også et relativt sjeldent symptom ved malignt melanom. Både atypiske pigmentnævi og malignt melanom kan ha uregelmessig form og farge. Dersom lesjonen har vært stasjonær over flere måneder uten tegn til endringer, taler dette for diagnosen atypisk pigmentnævus, ettersom et malignt melanom vanligvis vil vokse i utbredelse og/eller endre pigmentering over tid. Særlig karakteristisk for malignt melanom er utvikling av nye svarte partier ujevnt fordelt innen lesjonen.

Et malignt melanom er vanligvis større enn $5 \mathrm{~mm}$ i diameter. Pasienter kan derfor læres opp til å bli kjent med pigmenterte lesjoner som ikke lar seg skjule bak enden på en blyant - dette kalles gjerne for blyanttesten. Dersom en slik lesjon vokser i utbredelse eller endrer form/pigmentering, øker

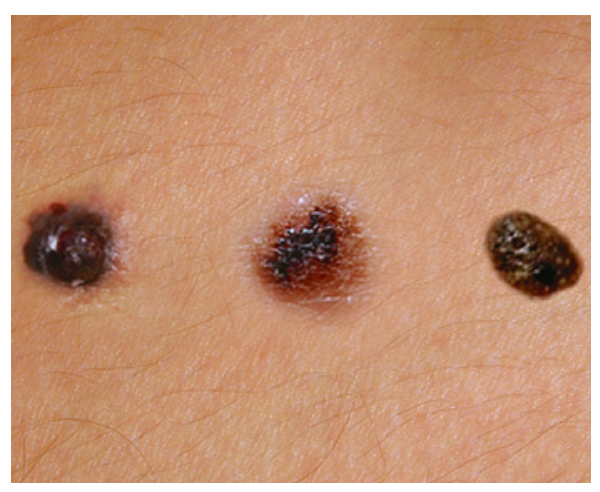

Figur 1 Fotomontasje av malignt melanom, atypisk pigmentnævus og talgvorte på huden

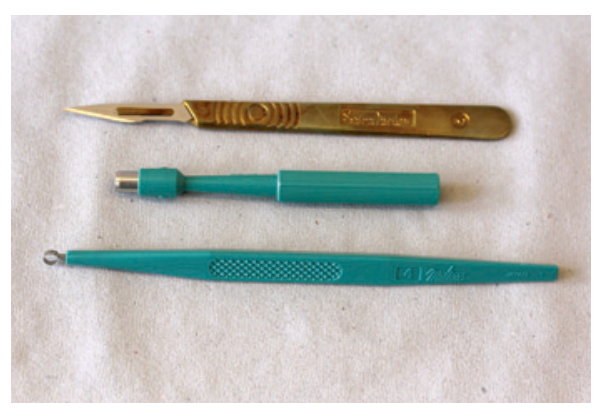

Figur 2 Nødvendig utstyr: kyrette, ringformet kniv (stanse) og skalpell 
Tabell 1 Viktigste differensialdiagnostiske kriterier for å skille malignt melanom fra seboreisk keratose og atypisk pigmentnævus

\begin{tabular}{|c|c|c|c|}
\hline & Seboreisk keratose & Atypisk pigmentnævus & Malignt melanom \\
\hline Anamnese & $\begin{array}{l}\text { Alder > } 30 \text { år } \\
\text { Utvekst } \\
\text { Rask vekst } \\
\text { Kløe, irritasjon } \\
\text { Ofte truncus }\end{array}$ & $\begin{array}{l}\text { Alder > } 20 \text { år } \\
\text { Noen liknende lesjoner } \\
\text { Ingen eller liten endring } \\
\text { lkke kløe } \\
\text { Ofte truncus }\end{array}$ & $\begin{array}{l}\text { Alder > } 20 \text { år } \\
\text { Solitær føflekkliknende lesjon som } \\
\text { har endret seg i farge og form } \\
\text { Svart komponent }(90 \%)\end{array}$ \\
\hline Funn & $\begin{array}{l}\text { Flere lesjoner av liknende art } \\
\text { Talgaktig } \\
\text { Verrukøs } \\
\text { Homogen } \\
\text { Kan være svart } \\
\text { Løsner i biter }\end{array}$ & $\begin{array}{l}\text { Pigmentert lesjon med uregel- } \\
\text { messig form, farge og størrelse } \\
\text { Flat komponent } \\
\text { Flere av likende utseende } \\
\text { lkke talgaktig }\end{array}$ & $\begin{array}{l}\text { Solitær } \\
\text { Pigmentert lesjon med svart eller hete- } \\
\text { rogent fargemønster som skiller seg } \\
\text { fra de andre } \\
\text { Ikke talgaktig konsistens }\end{array}$ \\
\hline Differensialdiagnose & $\begin{array}{l}\text { Melanom: } \\
\text { Ikke verrukøs } \\
\text { Mer heterogen i farge og form } \\
\text { Aldri flere lesjoner av samme type } \\
\text { Solar keratose: } \\
\text { Flat, tørr, erytematøs, sjelden } \\
\text { pigmentert }\end{array}$ & $\begin{array}{l}\text { Melanom: } \\
\text { Større uregelmessighet i farge, } \\
\text { svart farge, solitær }\end{array}$ & $\begin{array}{l}\text { Seboreisk keratose } \\
\text { Pyogent granulom: } \\
\text { Raskt voksende blødende tumor } \\
\text { Atypisk pigmentnævus: } \\
\text { Lite endring, mindre fargevariasjon } \\
\text { Pigmentert basaliom: } \\
\text { ofte flere mindre liknende lesjoner }\end{array}$ \\
\hline Diagnostisk prosedyre & $\begin{array}{l}\text { Kyrretering, lar seg skrape av med } \\
\text { lett blødning } \\
\text { Histologisk undersøkelse ved tvil }\end{array}$ & $\begin{array}{l}\text { Eksisjon med stanse hvis < } 6 \mathrm{~mm} \\
\text { eller vanlig båtformet totaleksisjon } \\
\text { Histologisk undersøkelse }\end{array}$ & $\begin{array}{l}\text { Eksisjon med } 2 \mathrm{~mm} \text { fri rand } \\
\text { Histologisk unders } \varnothing \text { kelse }\end{array}$ \\
\hline
\end{tabular}

mistanken om malignt melanom. Vi anbefaler da enten klinisk vurdering med eventuell eksisjon, eller henvisning til hudlege/ kirurg.

Dermatoskopi utført av erfaren skopør vil høyne muliheten til å kunne skille atypisk pigmentnævus fra malignt melanom (10).

\section{Diskusjon}

Vi har i denne artikkelen beskrevet de viktigste kliniske symptomer og tegn som skiller seboreiske keratoser og atypiske pigmentnævi fra maligne melanomer. Dersom det etter anamnese og klinisk undersøkelse fortsatt foreligger tvil om diagnosen, har vi presentert tre prosedyrer (med video) som en allmennlege bør kunne utføre for sikker avklaring av diagnosen. Vi tror økt bruk av disse prosedyrene kan gi tidligere diagnose og dermed bedre prognosen ved malignt

\section{RAMME 1 \\ ABCDE-regelen}

Det er en rekke tegn som kan skille malingt melanom fra en godartet pigmentnævus. Disse tegnene kan stilles opp i ABCDEregelen (7)

A: Asymmetri (to områder av føflekken har forskjellig form)

B: Begrensning (ujevn kant på føflekken)

C: Kulør (fargevariasjon med oftest svarte partier i føflekken)

D: Diameter (føflekken er over $6 \mathrm{~mm}$ i diameter)

E: Endring (føflekken vokser, eller endrer seg på annen måte slik det er beskrevet i punktene over) melanom. Samtidig kan en sikrere diagnose av seboreiske keratoser og atypiske pigmentnævi i allmennpraksis innebære raskere avklaring for pasientene, og færre henvisninger til spesialisthelsetjenesten.

\section{Claus Lützow-Holm \\ clau-lut@online.no \\ Petter Gjersvik \\ Per Helsing}

Claus Lützow-Holm (f. 1956) er dr.med. og spesialist i hud-og veneriske sykdommer og driver privat avtalepraksis.

Forfatter har fylt ut ICMJE-skjemaet og oppgir følgende interessekonflikter: Han har mottatt prosjektstøtte fra Den norske legeforenings fond for kvalitetsforbedring i forbindelse med utarbeiding av internettbasert opplæring.

Petter Gjersvik (f. 1952) er dr. med., spesialist i hud- og veneriske sykdommer og førsteamanuensis ved Institutt for klinisk medisin, Universitetet i Oslo.

Forfatter har fylt ut ICMJE-skjemaet og oppgir ingen interessekonflikter.

Per Helsing (f. 1958) er spesialist i hud- og veneriske sykdommer og overlege med malignt melanom som viktigste forskningsområde, ved Seksjon for hudsykdommer, Oslo universitetssykehus, Rikshospitalet.

Forfatter har fylt ut ICMJE-skjemaet og oppgir ingen interessekonflikter.

\section{Litteratur}

1. Marghoob AA, Braun RO, Kopf AW. Atlas of dermoscopy. London: Taylor and Frances, 2006.

2. Duffy K, Grossman D. The dysplastic nevus: from historical perspective to management in the modern era: part I. Historical, histologic, and clinical aspects. J Am Acad Dermatol 2012; 67: 1.e1-16, quiz 17-8.

3. Gandini S, Sera F, Cattaruzza MS et al. Meta-analysis of risk factors for cutaneous melanoma: I. Common and atypical naevi. Eur J Cancer 2005 41: $28-44$

4. Schopf T, Funk J. Føflekk eller malignt melanom? Tidsskr Nor Legeforen 2012; 132: 511.

5. Grob JJ, Bonerandi JJ. The «ugly duckling» sign: identification of the common characteristics of nevi in an individual as a basis for melanoma screening. Arch Dermatol 1998; 134: 103-4.

6. Friedman RJ, Rigel DS, Kopf AW. Early detection of malignant melanoma: the role of physician examination and self-examination of the skin. CA Cancer J Clin 1985; 35: 130-51.

7. Abbasi NR, Shaw HM, Rigel DS et al. Early diagnosis of cutaneous melanoma: revisiting the ABCD criteria. JAMA 2004; 292: 2771-6.

8. Goodson AG, Grossman D. Strategies for early melanoma detection: Approaches to the patient with nevi. J Am Acad Dermatol 2009; 60: 719-35, quiz $736-8$

9. Nasjonalt handlingsprogram med retningslinjer for diagnostikk, behandling og oppfølging av maligne melanomer. Oslo: Helsedirektoratet 2011

10. Carli P, de Giorgi V, Chiarugi A et al. Addition of dermoscopy to conventional naked-eye examination in melanoma screening: a randomized study 1997-2001. Br J Dermatol 2004: 50: 683-9.

Mottatt 21.12. 2012, første revisjon innsendt 14.3 . 2013, godkjent 14.5. 2013. Medisinsk redaktør Vegard Bruun Wyller.

Engelsk oversettelse på www.tidsskriftet.no

Video på www.tidsskriftet.no

Publisert først på nett. 